net in-goings and output of matter by the animal body. Within the last fifty years the applicability of the principle of conservation of energy to animals has been established by Rubner. The energy-value of the important foodstuffs has been ascertained, and the requirements of the human body under various conditions of age, climate, and occupation have been determined.

This knowledge has been inadequately exploited because everyone prefers to be a law unto himself in the matter of food intake. It has served as a basis for the rationing of armies and for the construction of institutional dietaries. During recent years, however, it has become increasingly apparent that man cannot live on protein, fat, and carbohydrate alone, but that a diet must contain in addition small quantities of what, until they can be isolated and identified, have been designated "accessory food factors." The best example of these is the for long recognised antiscorbutic substance in fresh vegetables and fruits. The existence of at least three accessory food substances has been since established. For all of these the animal is dependent directly or indirectly upon the vegetable kingdom. An insufficient supply of any one of these leads to trouble. If one of them is inadequate, scurvy results; deficiency of another leads to the disease beriberi; and if deprived of the third an animal fails to grow. There appears also to be no doubt that rickets in children is due to a similar cause.

This knowledge has for long been utilised to prevent scurvy. Where it has been intelligently applied it has eliminated beri-beri from cooliecamps, the population of jails, and industrial com- munities of the Far East, and if it is utilised in the efforts to feed the famished population of the unfortunate countries of Eastern Europe it will be the means of saving thousands of young lives during the ensuing winter.

Science has also been successfully applied in recent years to the diminution of the dangers incident upon certain industrial occupations, such as mining, caisson working, and deep-sea diving. During the last ten years, too, the influence of industrial fatigue, alcohol, improper atmospheric conditions in workshops, etc., upon the health and efficiency of the worker has been seriously studied. In these inquiries America has shown the greatest energy, but in Britain the subject is beginning to receive the attention its importance demands.

It is impossible to assess the effect of preventive medicine and improved hygienic surroundings upon the health and happiness of mankind; but the influence upon longevity can, in the case of civilised communities, be determined. During the last fifty years upwards of ten years have been added to the mean expectation of life of a child born in Britain or in the United States of America. An increase of 25 per cent. in so short a time is cause for congratulation, but, on the other hand, the fact that a million young men were found unfit for active service indicates that all is not well with Britain.

We are still far from the possession of sufficient knowledge to regulate satisfactorily our environment or to avoid all noxious influences, but owing to lack of power, money, or sometimes sense, we apply far less than we possess.

\title{
THE ANTIQUITY OF MAN
}

\section{By Dr. A. Smith Woodward, F.R.S.}

A T the beginning of the Tertiary period, when mammals began to spread widely over the world, they were all very small and so uniform in character that it is scarcely possible to classify them into groups or orders. They all had a comparatively small brain of a simple kind, and as in course of time they became gradually subdivided into the groups with which we are now familiar, the brain increased both in size and effectiveness, while many of the animals themselves grew larger. In the middle and towards the end of the earliest Tertiary (Eocene) epoch some of the low-brained hoofed mammals attained their greatest size and then became extinct. Next in the Oligocene another group with somewhat improved brain grew even larger just before extermination.

In the following Miocene epoch several groups that had by that time acquired a still more efficient brain, such as rhinoceroses, horses, certain carnivores, and primitive elephants, attained a comparatively large size and soon reached their maximum in the Pliocene. About the middle and towards the end of the Miocene epoch true apes, NO. $26 \mathrm{IO}$, VOL. IO4] with a higher development of brain than any mammal up to that time had acquired, also began to grow to as large a size as most of the apes of the present day. It may therefore be predicted that the earliest remains of the largest members of the ape-series, with a truly overgrown brain-the great ground-apes which were the im. mediate forerunners of man-will not be found in rocks of older date than the Pliocene, and probably not in any but the latest of this epoch. For other reasons Sir William Boyd Dawkins came to the same conclusion so long ago as 1880 , and as discoveries progress it becomes increasingly clear that true man, of the family Hominidæ, cannot be earlier than late Pliocene or the dawn of the Pleistocene.

So few fragments of apes and man have hitherto been met with that it is difficult to decide upon the region of the world that may be most hopefully searched. If, however, conclusions may be drawn merely from teeth, the most promising field at present seems to be south-central Asia. By the discovery of such teeth, Dr. Pilgrim has 
shown that a varied assemblage of apes lived in the forests of northern India in the Miocene epoch. At that time the Himalayan Mountains did not exist, and the late Joseph Barrell ingeniously suggested that it may have been during the uplift of this mountain range at the end of the Miocene and beginning of the Pliocene that primitive man originated. As the land rose, the temperature would be lowered, and some of the apes which had hitherto lived in the warm forest would be trapped to the north of the raised area. As comparatively dry plains would there take the place of forests, and as the apes could no longer migrate southwards, those that survived must have become adapted for living on the ground, and acquired carnivorous instead of frugivorous habits. By continued development of the brain and increase in bodily size, such ground-apes would tend to become man.

Unfortunately, we are still ignorant of fossils to test this hypothesis. We know from fragments of jaws, isolated teeth, and one limb bone that generalised apes as large as chimpanzees existed in Europe so far north as the latitude of Darmstadt until the end of Miocene times, but the only giant ground-ape, which many have claimed to be an ancestral man, was found by Dubois in Java in deposits of much later age which may even be Pleistocene. Pithecanthropus erectus, as the Javan species is named, is still known only by a cranial roof, two molar teeth, and a diseased thigh-bone, which bear many resemblances to the corresponding parts of the existing gibbon, and are tantalising in their imperfection.

It is, however, curious that almost the only traces of true man hitherto found with distinctively ape-like characteristics are from Western Europe. The imperfect skull and mandible of Eoanthropus dawsoni discovered by the late Charles Dawson at Piltdown, Sussex, represents a man with the lowest of all known human brains, and with an ape-like jaw in which typically human molar teeth are accompanied by large canines as completely interlocking as in any ape. The massive lower jaw of Homo heidelbergensis from Mauer, near Heidelberg, still retains much reminiscence of an ape in its retreating chin. The fine skeleton of Neanderthal or Mousterian man described by Prof. Marcellin Boule from LaChapelle-aux-Saints, France, combines more apelike features in a single individual than are known in any existing man. The Piltdown and Heidelberg fossils are shown by associated mam. malian remains to date back at least to the beginning of the Pleistocene, perhaps even to the end of the Pliocente epoch. Neanderthal man is later, and is very soon followed by typical modern man.

As to the actual age of these various remains in years or centuries there has been much discussion, but it must be confessed that on present evidence only vague guesses are possible. It is true that Penck and Brückner have made some plausible suggestions as to the length of Pleistocene time based on their studies of the glaciation of the Alps. Baron de Geer has also been able to date more precisely the retreat of the Pleistocene ice-sheet in Scandinavia by counting the annual layers in the mud which its flood-waters left behind. It is impossible, however, with our present knowledge, to correlate the isolated patches of Piltdown gravel, Mauer sands, or cavern deposits with the surface phenomena of distant areas; and it is doubtful whether this difficulty will ever be overcome.

Our knowledge of the ancestry of man has, indeed, progressed much during recent years, but unfortunately it is necessary to depend on accidental discoveries. Systematic exploration seems to meet with little or no result. Mrs. Selenka made great and prolonged excavations in Java in the river-deposits whence Pithecanthropus was obtained, without any success. The great sandpit at Mauer has been continuously worked and most carefully watched since the famous jaw was discovered, but without recovering any further traces of man. I have worked. hard in the Piltdown gravel, but for the last three seasons I have not found a fragment of either bone or tooth. The research needs much patience, but we may hope that as interest in the subject is more widely spread a larger proportion of the accidental finds relating to it will escape destruction.

\section{THE PRESENT POSITION OF THE MUTATION THEORY.}

\section{By Prof. Hucio de Vries.}

D ARWIN assumed that species originate by the gradual accumulation of infinitesimal, ordinarily invisible variations on account of their utility in the struggle for life. The difficulties inherent in this conception have led to the theory of mutation, which supposes that the production of species and varieties proceeds by small but distinct steps, each step corresponding to one or more unit-characters. It is only after their appearance that the environment can decide about their utility.

The new theory reduced the time necessary for NO. 26 IO, VOL. IO4]. the evolution of organic life on earth to the limits deduced by Lord Kelvin and others from physical and astronomical data. It explained the appearance of the numerous useless qualities of animals and plants, and eliminated the objection that the first almost imperceptible changes could scarcely have any beneficial significance for their bearers. It developed the doctrine of two essential types of variability, which are now called fluctuating variability and mutability. The first of these describes the small but always present differences among individuals of the same stock, whereas 